\title{
(息)
}

Citation:

Matthias, O and Campbell, J (2017) Consultancy in Management Education. In: Management Consultancy Insights and Real Consultancy Projects. Routledge, Aldershot, pp. 108-116. ISBN 9781472479297

Link to Leeds Beckett Repository record:

https://eprints.leedsbeckett.ac.uk/id/eprint/6935/

Document Version:

Book Section (Accepted Version)

This is an Accepted Manuscript of a book chapter published by Routledge in Management Consultancy Insights and Real Consultancy Projects on 02 October 2017, available online: http://www.routledge.com/9781472479297

The aim of the Leeds Beckett Repository is to provide open access to our research, as required by funder policies and permitted by publishers and copyright law.

The Leeds Beckett repository holds a wide range of publications, each of which has been checked for copyright and the relevant embargo period has been applied by the Research Services team.

We operate on a standard take-down policy. If you are the author or publisher of an output and you would like it removed from the repository, please contact us and we will investigate on a case-by-case basis.

Each thesis in the repository has been cleared where necessary by the author for third party copyright. If you would like a thesis to be removed from the repository or believe there is an issue with copyright, please contact us on openaccess@leedsbeckett.ac.uk and we will investigate on a case-by-case basis. 


\section{Consultancy in Management Education}

\section{Abstract}

The chapter interrogates the teaching and application of management consultancy as part of an MBA and examines its relevance in management education. Mature and experienced students, many with impressive CVs recording multiple career successes, demand that the core experience of their MBA programmes provide opportunities to apply theoretical knowledge in real-life situations. The further opportunity to work with blue-chip clients on some of their projects of strategic importance offers further opportunities to test management thinking and consultancy practise in a robust and challenging manner. Students often have experience of working with consultants previously, but most have little experience of managing and delivering projects for clients within a consultancy framework. The pedagogical challenge is to teach students the true value proposition in consultancy beyond the transactional relationship inherent in answering a problem question set by the client. The basic process approach moves students from considering consultancy as a phenomenon that 'happens' to a client with a solution magically appearing upon project conclusion, to a position where students recognise consultants as a true 'change agent', unfreezing clients from previous positions and realising new capabilities (Lewin, 1951). There is an examination of ensuring the relevance of the management consultancy approach to students as part of their MBA journey as well as relevance to the client companies in engaging with the University. There is discussion on how teaching a rigorous approach to management consultancy project management and research-orientated methodology retains the focus on the impact to the client organisation (Applebaum and Steed, 2005). There is consideration of how true impact on client companies is achieved by ensuring legacy forms part of expectation management (Kirk, 2000) with client companies keen to reengage with future MBA student teams. The chapter concludes with a reflection on future development of consultancy within management education, and how that embeds theoretical learning with individual context. 


\section{INTRODUCTION - DESIGNING A NEW MBA}

For many years, Business Schools have incorporated aspects of management consultancy into their MBA programmes, either through specific consultancy modules or through offering consultancy projects. Many of the modules in Management Consultancy are accredited by the CMI for the Level 7 Diploma in Professional Consulting. Given that MBA graduates tend towards consultancy as the career of choice following their qualification, many students choose the module because of its content and the additional qualification they receive. Those Schools who have chosen to go down the path of offering consultancy projects have found both difficulties and rewards arising from their choice.

This chapter uses a specific example of the experience of one Business School and how its programme has evolved in regard to management consultancy projects during the course of MBA study. The initial driver, a little over 10 years ago, in mid-2006, for considering such an approach was the decision to launch a full time MBA. The University of East Anglia contemplated the fact that the MBA market was already crowded and realised that if their new programme were to succeed, they had to offer something different to aspiring management professionals who were keen on investing in MBA study as the catalyst to helping them secure more advanced leadership positions. Prospective candidates consistently stated that beyond the standard syllabus covering the key areas of business and management strategy, they wanted an experience that allowed them to put theory into practice. This needed to be academically robust, beyond the 'interesting project' experience, demonstrating how MBA-level thinking could be applied and implemented to effect real change in organisations.

Fortunately, an element to their already-established Executive MBA, invited students to work with blue-chip companies in the Czech Republic. This had been developed by Professor Emeritus Roy McLarty, a formerly a member of the faculty delivering that programme. There was therefore a degree of organisational competence in the mechanics of working with large companies at a senior level and a number of senior relationships in that regard. In addition, they recruited Terry Kendrick who had a number of years' experience as an independent management consultant. 
Although Terry has now left and is at the Leeds Business School, he was instrumental in developing this aspect of the Full Time MBA programme. The innovation at the time was to offer students the opportunity to complete management consultancy projects in organisations willing to open themselves up to this kind of exposure. The objective was to deliver strategic and practical recommendations to a range of client organisations.

The Management Consultancy Project element to the MBA is now the substantive element to the course, carrying 40 of the 180 credits required for the qualification, replacing the more usual dissertation component. Through close cooperation with the Institute of Management Consulting (now part of the Chartered Management Institute) regarding syllabus development, MBA graduands are dual qualified, with both their Master's degree and the Diploma in Professional Consulting. The University of East Anglia have the distinction of being the first MBA course in the UK to offer this combination.

\section{THE CHALLENGE OF RECRUITING CLIENTS AND DEMONSTRATING RELEVANCE}

Although companies were willing to collaborate and work in partnership with Business Schools on events, research collaborations, or employability-themed initiatives that helped them recruit new talent, offering projects for students to work on was not something they were willing to embark upon. Despite pre-existing working relationships, recruiting clients for this aspect was a struggle. Companies stated they were reluctant to undergo the potential discomfort of having a group of experienced managers who were studying for an MBA accessing and then commenting on important elements of the operations of their business.

Serious consideration had to be given to how this could be changed. If the programme were to succeed, this innovative aspect had to be implemented. Much as the theory of client:consulting relationships advocates, the University of East Anglia had to engage with the businesses they already were working with in a new way. If they could not succeed in existing relationships, it was felt that expanding this idea to new businesses might be irrevocably compromised. The approach adopted was one advocated by Cialdini (1993). 
The first step was persuading clients that there was real commercial value (for which they would not have to pay!) in the work the students would carry out for them. Success was slow and based on targeting carefully which businesses with existing relationships would be approached. In selectively choosing the clients they were prepared to work with, and emphasising the selective nature of recruitment of candidates to the MBA programme - not quite the 'best of the best' - but a sufficient statement of quality to create a desire in prospective clients to want to work with the students, there came a shift in demand from 'push' to 'pull' in classic consultancy client management terms (Cope 2003). Reciprocity and scarcity were key influencing factors and helped build trust in a structured way for what became an unwritten contract about working together institutionally.

Success in this regard then created a different challenge - to ensure the module was designed in such a way that it enabled students to deliver on the inherent promise underpinning the company:university contract. Much like the client:consultant relationship itself, where the firm's brand provides a kind of corporate banner associated with a track record of successful collaboration (Matthias 2013), by association, the students are associated with this relationship between organisation and University. As such, this creates an expectation by the company which the student, as representative of the University in this instance, must fulfil. Thus the basis of the framework for the student project is formed from a relationship standpoint.

To ensure the University maintains its reputation then, from both a current and future student perspective, and in terms of continuing successful engagement with business, the first step had to be to engage the students and create an appetite for success in a structured yet flexible way. Thoroughness and creativity, sometimes seen as opposing traits, had to be built into the programme and needed to be a student learning outcome.

\section{METHODOLOGY AND FOCUSSING ON PERFORMANCE}

Undoubtedly, many people are prejudiced against the consulting industry as a result of consistently negative media exposure and coverage of high-profile project failures (BBC 2013, McDonald 2013). Despite this, consultancy draws in many people. As well as being inherently interesting in and of itself of course, the skills and techniques learnt for 
management consultancy are easily transferable to any management role because of the results-driven focus, which is achieved through the deployment of quantitative, research, and problem-solving skills, seamlessly married with the so-called 'soft' interpersonal skills of negotiation, facilitation, coaching, and communication.

The first step to generate success, for the programme, the clients and the students themselves therefore, even for students who had worked with consultants in their own organisations previously, had to be to open up students' minds to considering management consultancy in a new light. A little humour begins this process. Lectures begin with lighthearted references to pictures of J K Rowling's Harry Potter character and Charles Darwin. In this way, students are challenged to reject the myth that effective consultancy is a smokeand-mirrors parlour game where solutions emerge at the end of the project through the 'wizard' or 'guru' mode (Clark and Greatbatch 2002, Clegg et al. 2004, Johansson 2004). The assertion is that good consultancy remains true to the definition:

"A contracted service delivered by specially qualified individuals who assist and support in an objective and independent manner. Management Consultants identify management problems, analyse the cause of such problems, recommend solutions and help - where requested - in the implementation of solutions" (Greiner and Metzger 1983).

This definition is a consistent theme throughout the module, and principles such as objectivity and the need to work towards practical solutions is paramount throughout. Also emphasized throughout the programme is value, as understood in an element of the recognised definition of consultancy published by the Management Consultancy Association:

"The creation of value for organisations, through the application of knowledge, techniques and assets, to improve business performance." (MCA 2016).

The core structure of the syllabus provides an outline of the core features of consulting work:

- process approach

- business research methodologies 
- client management

- project management

- delivery

Essentially these features are about the ability to address high level problems, whether as an employee or a consultant. From the perspective of an MBA programme, these aspects, incorporated into this module, provide the opportunity to draw upon and integrate the knowledge base from the other MBA units within a taught framework of management consultancy skills. This module offers opportunities to apply previously taught tools and techniques and reflection on personal development. Reflective practice and personal reflection have been found to enhance individual and organisational performance (Schön 1991, Moon 1999). Although in the high-pressured world of consulting there is not always the time for this kind of personal development, the firm, the individual and clients benefit (Adams and Zanzi 2005, Bradley et al. 2011, Brivot 2011).

Another feature is a focus on effective performance in a team environment. This is different to the ubiquitous 'teamworking' frequently incorporated into many programmes. The difference is that the former utilises individuals' contributions in group processes which then jointly contribute to the overall outcome rather than seeking to create a false perception that everything must be done as a group. Team selection, delegation, development and management of each feature are an important aspect. A particular example came to light in the Czech Republic, with the University's longstanding collaborating organisation Unilever. The pressure was such that the project launch and the team gelling was described by a number of participants as "Tuckman on steroids", based on the long-established work on teams carried out by Tuckman (1965). Well-functioning teams are often taken for granted so it is an aspect of the taught element of this module that is emphasised (Nelson and McFadzean 1998).

In the classroom sessions it is also pointed out that there is something often forgotten by scholars and practitioners alike - an additional stage to working in a team, and one which a management consultant may not be overtly familiar with but has experienced multiple times. This is 'mourning' (Tuckman and Jensen 1977). It happens at the end of every 
project, and also even when just one member is removed or changed, thus impacting performance, however inadvertently. Raising awareness of team theory links strongly to the personal reflective learning component, and students are particularly asked to give consideration to the activity within teams so that they can reflect on their associated learning from that. It is highlighted that they can learn from positive and negative experiences. 'How not to' is sometimes better embedded as a learning experience than 'how to'.

Students apply this theoretical learning to scenarios and discussions during the in-class work, and then have the opportunity to explore the application further, during the two real live consultancy projects they undertake. All contributors to the programme, companies and students alike, emphasise the absolute necessity of practical recommendations and the requirement for the absence of superficiality and soundbites.

Together the aspects outlined, build to a significant individual piece of assessment over the year, and thus justifiably comprise such a large component of the MBA degree.

\section{ENSURING LEGACY AND IMPACT}

One important element of successful consultancy interventions is remaining focused on improving the performance of the client organisation (Appelbaum and Steed 2005).

Big impact - important recommendation - Kodak

\section{WHERE ARE WE NOW AND WHERE DO WE GO FROM HERE?}

As with all service businesses, delivering good quality service and creating client satisfaction is critical to establishing long-term relationships and gaining repeat business. Typically clients are keen on working with the University again and generate 'repeat business'. This demonstrates a satisfaction with the service, the outcomes and the relationships, in keeping with good consulting practice (Patterson 2000, Armbruster 2006). It also extends beyond the annual project phenomenon. In many of the client companies there is a curiosity arising. Questions are triggered, prompting a proactive search for ways of engaging, both further and differently. Questions such as: "What can we do with this next time around?" "Can we use the students to challenge our internal cultural boundaries?" and "Maybe the 
MBA consultancy team can address the unspoken shibboleth that nobody who works here can take the risk to address...." It is almost as if an adventurism has been awakened within these clients that would not perhaps be present in a commercial consultancy arrangement. Perhaps also it is the kind of 'nice to have' thinking that is rarely, if ever, part of a commercial agreement. Much as reflection is a part of studying this module before the client-facing work begins, so it would appear that it buys time in the client organisation. It is another manifestation of the 'bricolage' Bradley et al. (2011) referred to when discussing the need for creating the time to think and reflect, this time from the perspective of the firm - so organisational rather than personal development, but on a gently rather than transformational scale.

More here about clients taking an active interest in co-design of the course moving forward.

\section{CONCLUSION}

The University of East Anglia never sought to develop an MBA which would be the MBA for management consultants, although many of its MBA alumni gravitate towards careers in the consulting sector, anecdotally more so than from many other MBA courses in the UK. What they have found however, is that it is the consultancy education and experience that has proven to be the foundation of the future success for those who have experienced the course.

Good management consultancy is about client management, effective project discipline, and productive teamwork when under pressure. It is about building a case for change based on credible research and robust diagnostic analysis which includes the capability to identify assumptions, evaluate statements in terms of evidence, detect false logic or reasoning, identify implicit values, define terms adequately and generalise appropriately. Other core skills are critical thinking and creativity, managing creative processes in self and others, organising thoughts, analysis, synthesis, and critical appraisal. These days, good management is about every one of these skills too. Little wonder then that these are invaluable skills that MBA students are looking to develop to a higher level.

The vehicle for this learning at the University of East Anglia is the Management Consultancy Projects module within the MBA. The extra value in a strict consultancy sense is the 
application of recognised consultancy methodologies and an emphasis on value through practical solutions. As already stated, these are design elements to this management education experience that are incredibly portable in a career and career progression sense. The pedagogical framework developed for this module offers academic veracity and rigour, but its value goes beyond merely teaching and testing management consultancy projects. Management education is necessarily broad: students are from diverse sectors and professional backgrounds and have a variety of aspirations: promotion, career change, selfemployment. Consultancy, as a business professional broad church offers the scope to achieve this goal.

Plans to further develop the programme are in train. Reflection on the need to continue to ensure the resonance created and identified in the value proposition of the MBA course is continuous. For support and input, developments in the profession are looked to and sought out. However, for true inspiration it is to the body of clients who have worked with the University over the last 10 years that the team look. The clients have observed that working with students in this consultancy capacity has revealed things about their organisations that were unexpected. The invocation of the law of unintended consequences has not really revealed operational 'unknowns' (although that has happened) but a new light has been shed on the cultural, the social and the nature of professional relationships.

This has led to more companies expressing a desire to work as engaged clients, beyond just the 'commercial' aspect of the MBA project. Recent developments have been in regard to engaging with social enterprise activity with senior managers, to offering ideas and suggestions for new ventures and to mentoring staff and previous client-consultant contacts. What began as a transactional collaboration between the University and an external company has resulted in the wholly unexpected outcome of collaboration amongst a constantly changing team of equals coming together formally and informally to the rhythm of the academic year for mutual benefit. A key challenge for the future design of the course is to maintain that momentum and continue reaping the benefit of academic rigour with commercial need for value-added outcome for both business and University. 


\section{REFERENCES}

Adams, S. M. and Zanzi, A. (2005) "The Consulting Career in Transition: From Partnership to Corporate". Career Development International, Vol. 10 No. 4, pp 325-338.

Appelbaum, S. H. and Steed, A. J. (2005) "The Critical Success Factors in the ClientConsulting Relationship". The Journal of Management Development, Vol. 24 No. 1/2, pp 6893.

Armbruster, T. (2006) The Economics and Sociology of Management Consulting. Cambridge University Press, Cambridge

BBC (2013) NHS IT System One of 'Worst Fiascos Ever'. London: BBC. Available from: http://www.bbc.co.uk/news/uk-politics-24130684 (Accessed 23rd September 2012).

Bradley, S. W., Shepherd, D. A. and Wiklund, J. (2011) "The Importance of Slack for New Organizations Facing 'Tough' Environments". Journal of Management Studies, Vol. 48 No. 5, pp 1071-1097.

Brivot, M. (2011) "Controls of Knowledge Production, Sharing and Use in Bureaucratized Professional Service Firms". Organization Studies, Vol. 32 No. 4, pp 489-508.

Cialdini, R. B. (1993) Influence : The Psychology of Persuasion. Revised ed. Morrow, New York

Clark, T. and Greatbatch, D. (2002) Knowledge Legitimation and Audience Affiliation through Storytelling: The Example of Management Gurus. In: Clark, T. andFincham, R. (Eds.) Critical Consulting. New Perspectives on the Management Advice Industry. Oxford: Blackwells, pp. 152-171.

Clegg, S. R., Kornberger, M. and Rhodes, C. (2004) "Noise, Parasites and Translation: Theory and Practice in Management Consulting". Management Learning, Vol. 35 No. 1, pp 31-44.

Cope, M. (2003) The Seven Cs of Consulting : The Definitive Guide to the Consulting Process. 2nd ed. FT Prentice Hall, London

Greiner, L. E. and Metzger, R. O. (1983) Consulting to Management. Prentice-Hall, Englewood Cliffs; London

Johansson, A. W. (2004) "Consulting as Story-Making". Journal of Management Development, Vol. 23 No. 4, pp 339-354.

Matthias, O. (2013) Developing a Customisation Blueprint for Management Consultancies to Better Serve Their Clients. DBA. University of Bradford School of Management.

MCA (2016) The Consulting Industry. Management Consultancies Association: Online. Available from: http://www.mca.org.uk/about-us/the-consulting-industry (Accessed 1st July 2016). 
McDonald, D. (2013) The Firm : The inside Story of Mckinsey : The World's Most Controversial Management Consultancy. Simon \& Schuster, New York

Moon, J. A. (1999) Learning Journals : A Handbook for Academics, Students and Professional Development. Kogan Page, London

Nelson, T. and McFadzean, E. (1998) "Facilitating Problem-Solving Groups: Facilitator Competences". Leadership \& Organization Development Journal, Vol. 19 No. 2, pp 72-82.

Patterson, P. G. (2000) "A Contingency Approach to Modeling Satisfaction with Management Consulting Services". Journal of Service Research, Vol. 3 No. 2, pp 138-153.

Schön, D. A. (1991) The Reflective Practitioner : How Professionals Think in Action. Ashgate, Aldershot

Tuckman, B. W. (1965) "Developmental Sequence in Small Groups". Psychological Bulletin, Vol. 63 No. 6, pp 384-399.

Tuckman, B. W. and Jensen, M. A. C. (1977) "Stages of Small-Group Development Revisited". Group \& Organization Management, Vol. 2 No. 4, pp 419-427. 